[Annals N. Y. AOad. ScI, Vol. XVIII, No. 10, Part III, pp. 425-429.

16 December, 1908.]

\title{
OUTLINE OF THE GEOLOGY OF LONG ISLAND, N. Y.'
}

By W. O. Crosby.

(Read before the Academy 5 October, 1908.)

The crystalline rocks (chiefly granitic and gneissic) outcropping in Astoria and Long Island City are the foundation or true bed-rock of Long Island geology. Their origin need not be considered here; for the geological history of Long Island begins with the development on this crystalline bedrock of the Cretaceous peneplain, with its heavy load of sediments. 'The Cretaceous was a period of slow subsidence, the land sinking beneath the sea slowly enough to permit its almost perfect planation by marine erosion. In other words, this peneplain has a dual origin, - subaërial and màrine; true peneplanation obtaining above sea level, and still more approximate planation below sen level. This seaward plain, in further contrast with the landward peneplain, was covered by the Cretaceous sediments by which it is still, in large part, protected. It is clearly indicated, where recently uncovered, in the straight crest line of the Palisades.

The progressive subsidence was favorable to the progressive landward overlap of the Cretnceous sediments, by virtue of which only the later divisions are exposed to observation, the true lower Cretaccous being confined to the continental shelf, beyond the existing shore line. The conditions were undoubtedly favorable, also, to the extensive subaërial decay of the crystalline rocks, thus furnishing in abundance the variegated clays and muscovitic or fluffy sands so characteristic of the Raritan formation. Marine planation was clearly favorable, too, to the elimination from the mechanical detritus of all decomposable materials, leaving a residuum of clean quartz sand and gravel, thus accounting for the Iloyd Sand and other highly quartzose members of the formation. The increasing remoteness and degradation of the lind finally made possible the deposition of the clay

${ }^{1}$ Published by persisston of the Chine Fogineer of the Board of Water Supply, City of New York. 
marls and greensand marls of the upper Cretaceous; and it is probable, as others have suggested, that the deposition was continuous without important break through Eocene time. The original inland extension of this mantle of conformable sediments is clearly indicated by the southeastward deflection of the Connecticut River at Middletown and of the Housatonic River in approximately the same latitude. Entering at these points upon the newly-formed coastal plain, the rivers, released from the control of the bed-rock structure, naturally took the most direct course seaward; and subsequently, through the erosion of the Cretaceous mantle, found themselves superimposed upon the bed-rock in the obliquely transgressive and unsympathetic relation which we now observe. The Hudson, on the contrary, has felt throughout its history the efficient control of the continental re-entrant into which it debouches.

The continental elevation which finally terminated the CretaceousEocene deposition was probably at least equal to the present relief of the Cretaceous peneplain, and it may have been much more than this. It made possible the rapid erosion of the uplifted sediments and, probably, the trenching of the underlying peneplain. From this time, apparently, dates the wide and deep transverse valley which divides the Cretaceous beds in the western part of Long Island and which Veatch has called the valley of Sound River. In this valley was deposited, probably by stream action, the so-called Jameco Gravel, containing a high percentage of granitic detritus, which Veatch has regarded as the product of early Pleistocene glaciation. The granite pebbles, although now in an advanced state of decay, are well rounded or water-worn, showing that they must have been firm and undecomposed at the time of their deposition. The composition of this gravel suggests that the post-Eocene elevation may have been suffcient to induce glaciation. But, whether of glacial or non-glacial origin, this dark gravel, which blends upward with clays of probable Tertiary age, should be referred to the Tertiary series and not to the Pleistocene.

During the deposition of the Jameco Grivel, the land subsided to a position of comparative stability at the Tertiary bnse-level and the development of the Tertiary or Piedmont peneplain, under the joint agency of subaërial and marine erosion, began. The fluvial portions of the Tertiary base level, developed, for the most part, on comparatively weak rocks, have gained general recognition as the broad valley floors of the Hudson, Connecticut and other rivers. But in New England, at least, the marine contribution to this base-level, developed chiefly on relatively resistant crystalline rocks, has usually failed of differentiation from the older and far more continuous and complete Cretaceous peneplain. Profiles normal to the coast show, nevertheless, a more or less distinct terrace, and show, further, 
that this far exceeds in extent and continuity the portions of the Tertiary base-level developed by fluvial erosion. In eastern Massachusetts, where, apparently, the exposure to the Atlantic surges was, as now, unrestricted, the Tertiary base-level has a broad and singularly perfect development; but on the coasts of Rhode Island and Connecticut, protected in Tertiary times, as now, by a cordon of islands and reefs, it is rather less distinct and continuous, though by no means wanting.

The planation of the uplifted and tilted Cretaceous sediments by the Tertiary sea progressed rapidly, developing the well-known unconformity at the base of the Miocene and furnishing, doubtless, the major part of the heavy bed of clay overlying the Jameco Gravel, which I have elsewhere correlated with the Chesapeake division of the Miocene and which Veatch has correlated with the Sankaty Head deposits of probable early Pleistocene age. This clay is predominantly dark and carbonaceous and abundantly characterized by lignite and segregations of iron sulphide,--characters which seem to forbid its correlation with the Pleistocene, and especially with the fossiliferous quartz sands of Sankaty Head. Certainly the fact that it passes downward into gravel containing decomposed granitic pebbles does not demand such correlation.

When, finally, the Tertiary sea had transgressed over the Cretaceous series and reached the crystalline bed-rack, marinc erosion was able, by virtue of the excessively slow subsidence, to accomplish its perfect work, reducing the-surface to a plane and the detritus to a residuum of indestructible quartz, which we now know as the "Yellow Gravel" and correlate chiefly, at least, with the Pliocene (Lafayctte). The composition of the Yellow Gravel is vastly significant, especially in its genetic relation to the pleneplain; and comparison with the Jameco Gravel should prove fatal to the suggestion of an ultimate glacial origin. Its volume is also impressive and, in view of the limited extent of the Tertiary peneplain, suggests derivation, in part, from the similar gravels of the Cretaceous series. As a result of the progressive subsidence during the deposition of the several Tertiary terranes, we find that in their areal relations the Jameco Gravel is very restricted; the Chesaperike Clay is less restricted, and the Yellow Gravel is virtually unrestricted.

Contrary to the views of several of the later workers in this field, I hold that the Pleistocene glacinl history of Long Island is relatively simple. The known facts appear to be satisfactorily accounted for by a single ice invasion; and correlation with the complex Pleistocene stages of the Mississippi Valley is certainly not demanded.

That the Pleistocene glacial period was, for this region, preceded and ushered in by a long-continued continental uplift is generally conceded, and 
we have positive proof in the submerged canyon of the Hudson of an elevation of approximately three thousand feet, or, according to Spencer, of nine thousand feet or more. From this elevation date the trenching of the Tertiary peneplain and its connecting base-leveled valleys and the main features of the modern coastwise topography, including the cuesta of Long Island and the inner lowland of Long Island Sound.

It appears most probable, as first suggested by Upham, that the Pleistocene ice-sheet originated in this latitude by accumulation, with the subsequent development by movement and ablation of a bold, aggressive, moraine-building front. The now drowned inner lowland of Long Island Sound is undoubtedly still floored by Cretaceous clays and sands. Across this floor, except at the narrow east and west ends, as shown by Merrill, the ground moraine was not dragged; and the erraties from the Connecticut shore must have been transported englacially, as also suggested by Merrill. The building of the moraines is due to the deformation by the thrust, and in part also by the vertical pressure, or dead weight, of the ice of the plastic Cretaceous clays and sands and the overburden of Tertiary gravel, and the incorporation in the latter, by the joint agency of the deformation and glacial streams, of the erratic detritus set free by the ablation of the ice.

- The transverse valleys and deep bays of the north shore of Long Island are probably in part pre-glacial,- original features of the cuesta and inner lowland. But in part, also, they must be attributed to the erosive action of the advancing ice, and to the occupation of pre-determined depressions by lobes of stagnant ice during the glacial retreat, while the bordering areas were being overspread by washed or modified drift, chiefly sand and gravel. In this connection it is interesting to note the close agreement in trend of these valleys with the glacial movement.

During the advance, as well as during the retreat, of the ice-sheet, conditions favored the formation of glacial lakes; and the outflowing glacial streams were, doubtless, building both delta and outwash plains of sand and gravel (earlier Manhasset gravels), derived chiefly from the deformed beds of Pliocene in turn, deformed by the continued advance of the ice and buried benenth the moraines. Thus deposits essentially contemporaneous with the moraines have come to be regarded as belonging to a distinctly earlier stage of the Pleistocene; and, apparently, sufficient account has not been taken of the disturbing and complicating agency of the ice acting in conjunction with the glacial waters, - fluvial and lacustral.

The recession of the ice margin, first from the outer, and later from the inner, moraine inaugurated anew general glacial-lake conditions along the 
north shore. The transverse valleys and bays were occupied by lobes of ice after the uncovering of the intervening peninsulas,--chielly irregular ridges of Cretaceous and Tertiary sediments and the earlier Manhasset gravels. Bordering the ice-lobes and overspreading the ridges was deposited a second series of deltas and outwash plains (later Manhasset gravels).

Both the earlier and the later Manhasset gravels merge outward with the moraines and the outwash plains, and, through these, are chronologically as well as stratigraphically continuous, the chief structural contrast being the general absence in the later Manhasset gravels of deformation due to glacial thrust.

The Manhasset was, in general, never continuous across the bays and harbors, toward which it still presents in part normal ice-contact slopes, and we are thus relieved of the necessity of attributing these wide and decp valleys to the erosive action in post-glacial time of the wholly insignificant tributary streams.

As noted by Woodworth and others, the bowlder bed conformably dividing the Manhasset Gravel on the west side of Hempstead Harbor is probably best explained as iceberg drift; and to the same agency, apparently, may well be referred, in general, the larger erratics scattered through and over the gravel. The so-called veneer of till over the undisturbed or later Manhasset Gravel, north of the moraine, seems to demand no other explanation. It is not a continuous body of drift, but it consists chiefly of widely scattering granitic bowlders devoid of clayey matrix, and is clearly recognizable in none of the numerous borings penetrating the Manhasset Gravel. In part, no doubt, it is till (ground moraine) which has not been completely covered by the modified drift (Manbasset Gravel).

The Iater Manhasset Gravel is in general entirely undisturbed and no where shows deformation that would not be readily accounted for by a relatively slight movement of the ice during its deposition. In short, proof that the later Manbiasset is older than the moraines or was ever over-run by the ire-sheet, is wanting; and henee it may fairly be regarded as the last chapter in the glacial history of Iong Island. The only important later contributions to the geology of the island are the post-glacial be:kh, dune and marsh depmits. It is especially noteworthy that there is no crictence of marine depesition during the Pleistoceme or between the Yellow (iracel (Lafayette) and the molern shore. 